TITLE:

\title{
Natural history of Camponotus ant- fishing by the M group chimpanzees at the Mahale Mountains National Park, Tanzania.
}

\author{
$\operatorname{AUTHOR}(S)$ :
}

Nishie, Hitonaru

\section{CITATION:}

Nishie, Hitonaru. Natural history of Camponotus ant-fishing by the M group chimpanzees at the Mahale Mountains National Park, Tanzania.. Primates 2011, 52(4): 329-342

\section{ISSUE DATE:}

2011-10

URL:

http://hdl.handle.net/2433/161793

\section{RIGHT:}

The original publication is available at link.springer.com; This is not the published version. Please cite only the published version.; この論文は 出版社版でありません。引用の際には出版社版をご確認ご利用くださ い。 
NOTICE: This is the author's version of the following article.

Nishie H (2011) Natural history of Camponotus ant-fishing by the M group chimpanzees at the Mahale Mountains National Park,

Tanzania. Primates 52: 329-342. DOI: 10.1007/s10329-011-0270-6.

(C) Japan Monkey Centre and Springer 2011. The original publication is available on SpringerLink at www.springerlink.com

\title{
Natural history of Camponotus ant-fishing by the M group chimpanzees at the Mahale Mountains National Park, Tanzania
}

\author{
Hitonaru Nishie \\ Wildlife Research Center, Kyoto University
}

\begin{abstract}
:
The aim of this study was to provide basic data on ant-fishing behavior among the $\mathrm{M}$ group chimpanzees at the Mahale Mountains National Park, Tanzania. Ant-fishing is a type of tool-using behavior that has been exhibited by Mahale chimpanzees when feeding upon arboreal carpenter ants (Camponotus spp.) since the 1970s, and is now regarded as a candidate of wild chimpanzee culture. Herein, I describe in detail the features of ant-fishing shown by the Mahale $M$ group chimpanzees: (1) 2 species of Camponotus ants (Camponotus sp. (chrysurus-complex) [C. sp.1] and C. brutus) were identified as the target species of ant-fishing, and $C$. sp.1 was selected intensively as the main target; (2) 24 species (92 individuals) of trees were identified as ant-fishing sites-these were widely distributed throughout the western/lowland region of the M group's home range, and the top 5 species were used more frequently; (3) the efficiency of ant-fishing was influenced not only by the site choice or the skillfulness of the chimpanzees, but inevitably by the condition of the ants; (4) the estimated nutritional intake from ant-fishing was apparently negligible; (5) most of the M group members (50/60 individuals) older than 3 years of age successfully used tools to fish for ants; and (6) female chimpanzees engaged in ant-fishing more frequently and for longer periods than males did. Further, I compared the features of ant-fishing exhibited by the Mahale $\mathrm{M}$ group chimpanzees with those exhibited by the former $\mathrm{K}$ group at Mahale and by other populations of wild chimpanzees.
\end{abstract}

Keywords: chimpanzee, tool-use, ant -fishing, Camponotus, Mahale, culture

\section{Contact address:}

Wildlife Research Center of Kyoto University, 2-24 Tanaka-sekiden-cho, Sakyo, Kyoto, 606-8203, Japan Phone: +81-75-7714387

Fax: +81-75-7714394

E-mail: nishie.hitonaru@gmail.com 


\section{Introduction}

Since the first observation of tool-using by wild chimpanzees at Gombe, Tanzania (Goodall 1963), many wild chimpanzee populations have been observed to use tools to feed on social insects [e.g., feed on termites with tools: Gombe (McGrew et al. 1979; Goodall 1986; Lonsdorf 2005), Kasakati (Tanzania: Suzuki 1966), Mahale (Tanzania: Nishida and Uehara 1980; Uehara 1982; McGrew and Collins 1985), Ndakan and Bai Hokou (Central Africa: Fay and Carroll 1994), Ndoki (Congo: Suzuki et al. 1995), Lossi (Congo: Bermejo and Illera 1999), Goualougo (Congo: Sanz et al. 2004), Campo (Cameroon: Sugiyama 1985; Muroyama 1991), Dja (Cameroon: Deblauwe et al. 2006), Belinga (Gabon: McGrew and Rogers 1983), Okorobikó (Equatorial Guinea: Jones and Sabater Pi 1969; Sabater Pi 1974), Bossou (Guinea: Sugiyama and Koman 1979; Humle 1999), Mt. Assirik (Senegal: McBeath and McGrew 1982; Bermejo et al. 1989), Fongoli (Senegal: McGrew et al. 2005; Bogart and Pruetz 2008); feed on driver ants with tools: Gombe (Tanzania: McGrew 1974), Kalinzu (Uganda: Hashimoto et al. 2000), Ngotto (Central Africa: Hicks et al. 2005), Gashaka (Nigeria: Fowler and Sommer 2007), Taï (Côte d'Ivoire: Boesch and Boesch 1990), Bossou (Guinea: Sugiyama et al. 1988; Sugiyama 1995; Humle and Matsuzawa 2002; Yamakoshi and Myowa-Yamakoshi 2004), Tenkere (Sierra Leone: Alp 1993), Fongoli (Senegal: McGrew et al.2005)]. These tool-using behaviors are regarded as 'culture' of wild chimpanzees, because these behavioral patterns are shared by many members of the communities and are maintained from one generation to the next by the process of social learning (reviewed in McGrew 1992, 2004, 2010; Whiten et al.1999, 2001).

This article focuses on ant-fishing, one of such tool-using behaviors exhibited by Mahale chimpanzees when feeding upon arboreal carpenter ants (Camponotus spp.). This behavior is composed of a sequence of 4 actions: (1) creating and modifying a fishing probe made of plant matter such as peeled bark, vine, branch, or midrib of leaf; (2) inserting the probe into the tree hole where wood-boring carpenter ants nest; (3) withdrawing the probe with the soldier ants; and (4) licking themoff with the lips and tongue (Nishida et al. 1999). After the first report from Mahale (Nishida 1973), ant-fishing has been recorded, including anecdotal and/or circumstantial evidence, in Assirik (McGrew 1983, McGrew et al. 2003), Lopé (Tutin and Fernandez 1992; Tutin et al. 1995), Gashaka (Fowler and Sommer 2007), Bossou (Yamamoto et al. 2008), and Gombe (O'Malley et al. 2010), but has never been reported from any other chimpanzee populations, despite the wide distribution of Camponotus spp. in Africa (cf. Bolton 1995; Yanoviak et al. 2007; Taylor 2010).

At Mahale, Nishida and Hiraiwa (1982) have already reported details of ant-fishing mainly by the $\mathrm{K}$ group chimpanzees. The K group became extinct in the 1980s, but until then they were a neighboring group of the $\mathrm{M}$ group that was the focus of the present study (Nishida et al. 1985). During the study period of Nishida and Hiraiwa (1982) in the 1970s, the K group chimpanzees were under artificial provisioning for habituation to human observers. Thereafter, provisioning at Mahale was reduced from 1981 and was completely abandoned from 1987 (Nishida 1990). In these respects, preceding studies indicated that tool-using behaviors by wild chimpanzees could be affected by various ecological factors such as food availability (Yamakoshi 1998), and that there were some variations in behavioral customs even between neighboring groups (McGrew and Collins 1985; Uehara 1982, 1986; McGrew et al. 2001; Nakamura and Uehara 2004; Sakamaki et al. 2007). Therefore, the aim of this study was to provide basic data on ant-fishing among the $\mathrm{M}$ group, which is the current main study group at Mahale, to compare the data with those obtained for the former $\mathrm{K}$ group and other populations of chimpanzees, in terms of behavioral variations and social customs, which are regarded as evidence of 'culture' in wild chimpanzees (Whiten et al. 1999, 2001).

\section{Methods}

\section{Study site and periods}

The subjects of this study were wild chimpanzees (Pan troglodytes schweinfurthii) of the $\mathrm{M}$ group in the Mahale Mountains National Park, Tanzania. Detailed information about Mahale is described elsewhere (Nishida 1990). Field observation was carried out in 2 study periods: from August 2002 to November 2002 (Period I), and from November 2003 to September 2004 (Period II). The composition of the $\mathrm{M}$ group during the 2 study periods is presented in Table 1 .

Table 1 Age/sex class composition of the M group chimpanzees during study period I and II

\begin{tabular}{|c|c|c|}
\hline Age/sex class ${ }^{\mathrm{a}}$ & Period I & Period II \\
\hline \multicolumn{3}{|l|}{ [Male] } \\
\hline Adult (16 years <) & 7 & $7-8^{\mathrm{b}}$ \\
\hline Adolescent (9-15 years) & 5 & 5 \\
\hline Juvenile (5-8 years) & 2 & 3 \\
\hline Infant $(0-4$ years $)$ & 5 & $3-6^{c}$ \\
\hline Total (Male) & 19 & $18-21$ \\
\hline \multicolumn{3}{|l|}{ [Female] } \\
\hline Adult $(13$ years $<$ ) & $19(16)^{d}$ & $22(16)^{\mathrm{d}}$ \\
\hline Adolescent (9-12 years) & $2-3^{\mathrm{e}}$ & 2 \\
\hline Juvenile (5-8 years) & 3 & 8 \\
\hline Infant $(0-4$ years $)$ & 10 & $5-7^{\mathrm{c}}$ \\
\hline Total (Female) & $34-35$ & $37-39$ \\
\hline Total (All) & $53-54$ & $56-60$ \\
\hline \multicolumn{3}{|c|}{$\begin{array}{l}\text { a Definition of age/sex classes according to Nishida et al. } 2003 . \\
\text { b } 1 \text { subject died in February } 2004 . \\
{ }^{c} 3 \text { males and } 2 \text { females were born during Period II. } \\
\text { d Numbers in parentheses indicate number of mothers with dependent } \\
\text { offspring. } \\
\text { e } 1 \text { subject immigrated in October } 2002 \text {. }\end{array}$} \\
\hline
\end{tabular}


Natural history of Camponotus ant-fishing by Mahale chimpanzees

\begin{tabular}{|c|c|c|c|c|}
\hline \multirow{3}{*}{$\begin{array}{l}\text { Table } 2 \text { Observation time in } \\
\text { each age/sex class including } \\
\text { focal and non-focal observation }\end{array}$} & \multirow{2}{*}{$\begin{array}{l}\text { Focal observation }(\mathrm{h}) \\
\text { Age/sex class }\end{array}$} & \multicolumn{2}{|c|}{ Study period } & \multirow[b]{2}{*}{ Total } \\
\hline & & Period I & Period II & \\
\hline & [Male] & & & \\
\hline & Adult (16 years <) & 98.48 & 431.51 & 529.99 \\
\hline & Adolescent (9-15 years) & 9.09 & 41.03 & 50.12 \\
\hline & Juvenile (5-8 years) & 21.63 & 17.82 & 39.45 \\
\hline & Infant ( $0-4$ years) & 5.31 & - & 5.31 \\
\hline & Total (Male) & 134.51 & 490.36 & 624.87 \\
\hline & [Female] & & & \\
\hline & Adult (13 years <) & $284.48(261.13)^{\mathrm{a}}$ & $711.05(684.50)^{\mathrm{a}}$ & $995.53(945.63)^{\mathrm{a}}$ \\
\hline & Adolescent (9-12 years) & 13.05 & 21.30 & 34.35 \\
\hline & Juvenile (5-8 years) & 36.26 & 57.53 & 93.79 \\
\hline & Infant $(0-4$ years $)$ & 31.55 & - & 31.55 \\
\hline & Total (Female) & 365.34 & 789.88 & 1155.22 \\
\hline \multirow{3}{*}{$\begin{array}{l}\text { a Numbers in parentheses indicate } \\
\text { focal observation hours of mothers } \\
\text { with dependent offspring. }\end{array}$} & Total (All) & 499.85 & 1280.24 & 1780.09 \\
\hline & Non-focal observation (h) & 134.24 & 265.68 & 399.92 \\
\hline & Total observation (h) & 634.09 & 1545.92 & 2180.01 \\
\hline
\end{tabular}

\section{Data collection and analysis}

Behavioral data were collected mainly by following a chimpanzee for as long as possible on each observation day. Focal individuals belonged to various age/sex classes, as shown in Table 2. The mean focal observation time per individual for each sex in the total of the 2 study periods was $56.81 \mathrm{~h}$ for males ( $624.87 \mathrm{~h}$ for 11 focal males) and $48.13 \mathrm{~h}$ for females ( $1155.22 \mathrm{~h}$ for 24 focal females). Additionally, I conducted ad libitum observation when it was difficult to follow focal individuals and before/after following a focal individual to check the members of the nomadic party in which the focal individual was included. Further, when I encountered a non-focal chimpanzee fishing for ants, I suspended the focal follow and recorded the ant-fishing details. The total observation time including such observations was $634.09 \mathrm{~h}$ in Period I, and $1545.92 \mathrm{~h}$ in Period II (Table 2).

At each ant-fishing site, I recorded the following data: individuals who engaged in ant-fishing; duration of the ant-fishing bout and session (defined below); and pause in the ant-fishing, e.g., for tool renewal or interruption by others. I also counted the number of ants consumed by chimpanzees in some favorable bouts during Period I, using binoculars and a counter. Because it was difficult to make separate counts of ants fished with tools and those eaten without tools, the data include both, without differentiating the ways the chimpanzees used to obtain ants.

To describe the frequency and the duration of ant-fishing, I defined bout and session according to Nishida and Hiraiwa (1982), with some minor modifications. A bout was defined as the period during which a chimpanzee was engaged in using tools to prey upon ants; the bout was terminated when the chimpanzee ceased ant-fishing for a period of $3 \mathrm{~min}$. If the individual resumed the tool-use after a period longer than $3 \mathrm{~min}$, I counted it as a different bout. Only when the tool-use was successful, i.e., a chimpanzee preyed upon at least 1 ant in consequence of using the tool, I regarded it as a bout. Thus, unsuccessful trials of tool-use were excluded from the following analyses. A session was defined as the period during which at least 1 chimpanzee was engaged in the tool-use at a host tree of ants on the same day; the session was terminated when the last chimpanzee of the party ended the tool-use activity and left the tree. Thus, a session included all the bouts observed at the same host tree of ants on the same day regardless of the length of the intervals between bouts. I differentiated the sessions during which a different host tree was used by the same individual on the same day and sessions during which the same tree was used on different days by the same individual. I observed 50 sessions in Period I, and 90 sessions in Period II. When analyzing the duration of bouts and sessions, I excluded incomplete data. For the analysis of the seasonality of ant-fishing, I only used the data collected during Period II.

To illustrate the repeated use of the host trees of ants, I numbered all trees used for ant-fishing with plastic labels, and recorded the location and the species of the trees. I also collected specimens of ants from some host trees for identification of the species.

Statistical analyses were conducted using the R software version 2.10.0 (The R Foundation, Vienna, Austria). The Wilcoxon rank sum test and Kruskal-Wallis test were used to compare independent two- and multi-group samples, respectively. For assessing the correlation between 2 independent group samples, Kendall's rank correlation coefficient test was conducted. The $\chi^{2}$ test was used to compare the collected data with the expected values (see footnotes in each Table). Significance level of all the statistical analyses was set at $\alpha<0.05$. 
Table 3 Host trees of Camponotus ants used as ant-fishing sites by the M group chimpanzees
${ }^{\text {a }}$ Density of each tree species on the phenology transect in the lowland forest of the $\mathrm{M}$ group home range (per 8.38 ha) (data from Itoh 2004).

\begin{tabular}{|c|c|c|c|c|c|}
\hline Tree species & Ant species & $\begin{array}{l}\text { No. of } \\
\text { trees } \\
(\%)\end{array}$ & $\begin{array}{l}\text { No. of } \\
\text { sessions } \\
(\%)\end{array}$ & $\begin{array}{l}\text { No. of } \\
\text { participants } \\
(\%)\end{array}$ & $\begin{array}{l}\text { Density } \\
(\%)\end{array}$ \\
\hline Spathodea nilotica & C. sp.1 & $20(21.7)$ & $35(25.0)$ & $117(27.2)$ & $6.32(10.6)$ \\
\hline Cordia millenii & C. sp.1 & $12(13.0)$ & $20(14.3)$ & $45(10.5)$ & $5.61(9.4)$ \\
\hline Cordia africana & C. sp.1, brutus & $11(12.0)$ & $20(14.3)$ & $75(17.4)$ & $3.82(6.4)$ \\
\hline Stereospermum kunthianum & C. sp.1 & $10(10.9)$ & $13(9.3)$ & $32(7.4)$ & $1.07(1.8)$ \\
\hline Combretum molle & C. sp.1 & $7(7.6)$ & $10(7.1)$ & $27(6.3)$ & $0.60(1.0)$ \\
\hline Pseudospondias microcarpa & C. sp.1 & $4(4.3)$ & $4(2.9)$ & $8(1.9)$ & $9.79(16.4)$ \\
\hline Canthium rubrocostatum & C. sp.1 & $3(3.3)$ & $4(2.9)$ & $19(4.4)$ & $0.36(0.6)$ \\
\hline Syzygium spp. & - & $3(3.3)$ & $3(2.1)$ & $14(3.3)$ & $1.07(1.8)$ \\
\hline Bridelia micrantha & C. sp.1, brutus & $2(2.2)$ & $4(2.9)$ & $11(2.6)$ & $0.12(0.2)$ \\
\hline Vitex doniana & - & $2(2.2)$ & $3(2.1)$ & $5(1.2)$ & $0.12(0.2)$ \\
\hline Diplorhynchus condylocarpon & C. sp.1 & $2(2.2)$ & $2(1.4)$ & $16(3.7)$ & - \\
\hline Markhamia hildebrandti & C. sp.1 & $1(1.1)$ & $3(2.1)$ & $10(2.3)$ & $1.43(2.4)$ \\
\hline Sterculia tragacantha & C. sp.1 & $1(1.1)$ & $2(1.4)$ & $4(0.9)$ & $2.74(4.6)$ \\
\hline Myrianthus arboreus & C. sp.1 & $1(1.1)$ & $1(0.7)$ & $7(1.6)$ & $1.31(2.2)$ \\
\hline Ficus exasperata & C. sp.1 & $1(1.1)$ & $1(0.7)$ & $5(1.2)$ & $8.11(13.6)$ \\
\hline Grewia mollis & C. sp.1 & $1(1.1)$ & $1(0.7)$ & $4(0.9)$ & - \\
\hline Tarenna pavettoides & C. sp.1 & $1(1.1)$ & $1(0.7)$ & $4(0.9)$ & - \\
\hline Uapaca nitida & - & $1(1.1)$ & $1(0.7)$ & $3(0.7)$ & $0.72(1.2)$ \\
\hline Trema orientalis & - & $1(1.1)$ & $1(0.7)$ & $2(0.5)$ & $0.12(0.2)$ \\
\hline Pycnanthus angolensis & - & $1(1.1)$ & $1(0.7)$ & $2(0.5)$ & $15.16(25.4)$ \\
\hline Pterocarpus tinctorius & - & $1(1.1)$ & $1(0.7)$ & $2(0.5)$ & $0.12(0.2)$ \\
\hline Monotes elegans & C. sp.1 & $1(1.1)$ & $1(0.7)$ & $1(0.2)$ & $0.12(0.2)$ \\
\hline Anthocleista sp. & - & $1(1.1)$ & $1(0.7)$ & $1(0.2)$ & $0.84(1.4)$ \\
\hline Terminalia sp. & C. sp.1 & $1(1.1)$ & $1(0.7)$ & $1(0.2)$ & $0.12(0.2)$ \\
\hline unidentified & - & $3(3.3)$ & $6(4.3)$ & $15(3.5)$ & - \\
\hline Total & & $92(100)$ & $140(100)$ & $430(100)$ & $59.67(100)$ \\
\hline
\end{tabular}

\section{Results}

\section{Target ant species of ant-fishing by the $M$ group chimpanzees}

I collected ant specimens from 49 of the 92 host trees used for ant-fishing. All the specimens were identified as either of the 2 species: Camponotus sp. (chrysurus-complex) (hereinafter called Camponotus sp.1), and Camponotus brutus (Forel) (identified by Dr. B. Bolton, The Natural History Museum, London). Both species were collected using fishing probes for consumption by the $\mathrm{M}$ group chimpanzees.

C. sp.1, black in body color with yellow-gold streaked pubescence (hair) on the dorsal side of the abdomen, was the major target of ant-fishing by the $\mathrm{M}$ group chimpanzees. Specimens of $C$. sp.1were collected from $98.0 \%$ (48/49) of the host trees belonging to 17 different tree species (Table 3). The frequent appearance of various tree species indicates that $C$. sp. 1 is, presumably, distributed widely over the $\mathrm{M}$ group's home range. The soldiers (body-length = ca. $10 \mathrm{~mm}$ ) and workers (body-length $=$ ca. $7-8 \mathrm{~mm}$ ) of this species were the main target of ant-fishing by the $\mathrm{M}$ group chimpanzees.

C. brutus was the second but presumably minor target of ant-fishing in the $\mathrm{M}$ group. Specimens of $C$. brutus were obtained from only 2 of 49 trees $(4.1 \%$; Table 3$)$. C. brutus has a black head, deep red-brown thorax, brown abdomen with deep brown-black stripes and golden pubescence (hair), and orange legs. Soldiers of $C$. brutus have a large body (body-length = ca. $15 \mathrm{~mm}$ ), a large head, and powerful mandibles. As described by Nishida and Hiraiwa (1982), soldiers of $C$. brutus are very aggressive. They come out of their nest more and more in response to the insertion of fishing probes and rapidly deploy on the surface of the tree where the chimpanzees sit, then make powerful bites that are enough to repel the chimpanzees fishing for ants. Chimpanzees bitten by this species of ants often show a grin-face and subsequently give up fishing for ants and escape from the site. Consequently, chimpanzees of the $\mathrm{M}$ group may rarely prey upon this species of ants using fishing tools. 


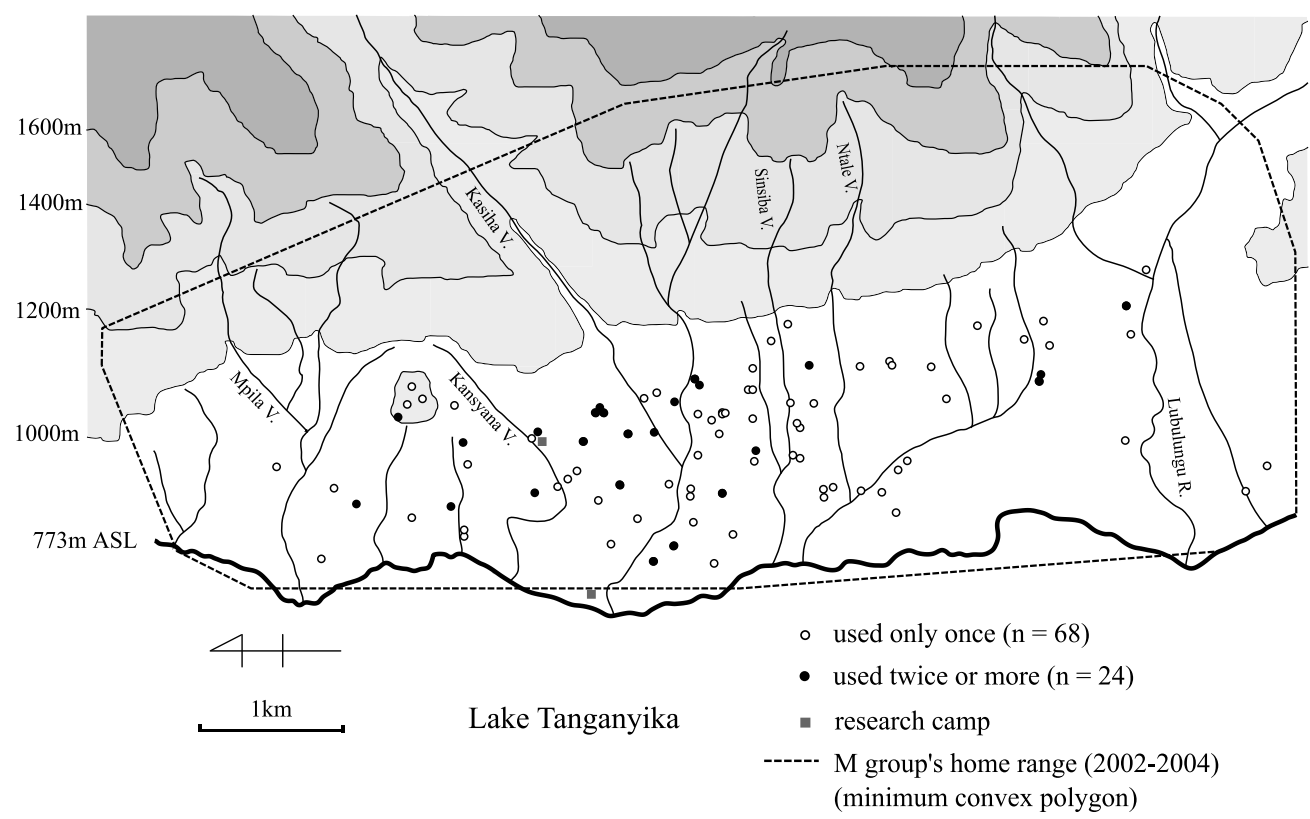

Fig. 1 Distribution of host trees of Camponotus ants used for antfishing by the M group chimpanzees. The M group's home range between 2002 and 2004 is depicted as the minimum convex polygon (Nakamura et al. 2011)

\section{Species composition and distribution of Camponotus ants host trees}

Ninety-two host trees used by chimpanzees as ant-fishing sites belonged to 24 species (Table 3). Among these, the top 5 tree species accounted for $65.2 \%(60 / 92)$ of the trees used for ant-fishing, $70.0 \%$ (98/140) of the observed ant-fishing sessions, and 68.8\% (296/430) of the observed ant-fishing participants.

Figure 1 shows the distribution of the host trees used for ant-fishing. The area shown in this figure covers almost the entire M group's home range. The ant-fishing sites were distributed only over the western side of their home range, where the lowland forest stretches from north to south along Lake Tanganyika. On the other hand, no ant-fishing was observed in the eastern/upper side of their home range, yet the tree species listed in Table 3 were distributed throughout both the western and eastern regions.

The $\mathrm{M}$ group chimpanzees more often used the top 5 tree species as ant-fishing sites than expected from the density of these species along the phenology transect [see Itoh (2004) and Itoh and Nishida (2007) for details on the transect] [top 5 species vs the other 16 species (excluding 3 species not available along the transect): $\left.\chi^{2}=70.4, d f=1, p<0.001\right]$.

\section{Number of ant-fishing sites and repeated use of trees}

Figure 2 shows the number of newly used host trees plotted against the number of observation days. The number did not reach a plateau, meaning that new host trees were adopted as ant-fishing sites even after 1 year of observation. This indicates that chimpanzees discover novel ant host trees one after another and that there might be a great number of ant host trees yet unknown for us.

Twenty-four of the 92 trees $(26.1 \%)$ were used in more than 2 sessions, and the remaining 68 trees were used only once (note that the number of repetitions is underestimated because of the incompleteness of observation). The most repeatedly used was a Spathodea nilotica tree, which was used in 6 sessions during the study periods. Of all the 140 ant-fishing sessions observed, 48 sessions (34.3\%) occurred at trees that had been used previously.

The cumulative number of chimpanzees who engaged in ant-fishing was 430 in all the 140 sessions (mean number of participants per session $=3.1$ ). The repeated use rate of a tree by the same individual chimpanzee was only $5.1 \%$ (22/430). This value was markedly lower than the repeated use rates of trees and of sessions (26.1 and 34.3\%, respectively). This indicates that the repeated use of a tree occurs with the shared or popularized knowledge among the many members of the $M$ group chimpanzees about the tree location where they repeatedly engage in ant-fishing. The knowledge is again renewed and shared through the repeated practice and observation of ant-fishing, rather than through each individual chimpanzee's independent memory or knowledge of the tree location previously used as an ant-fishing site.

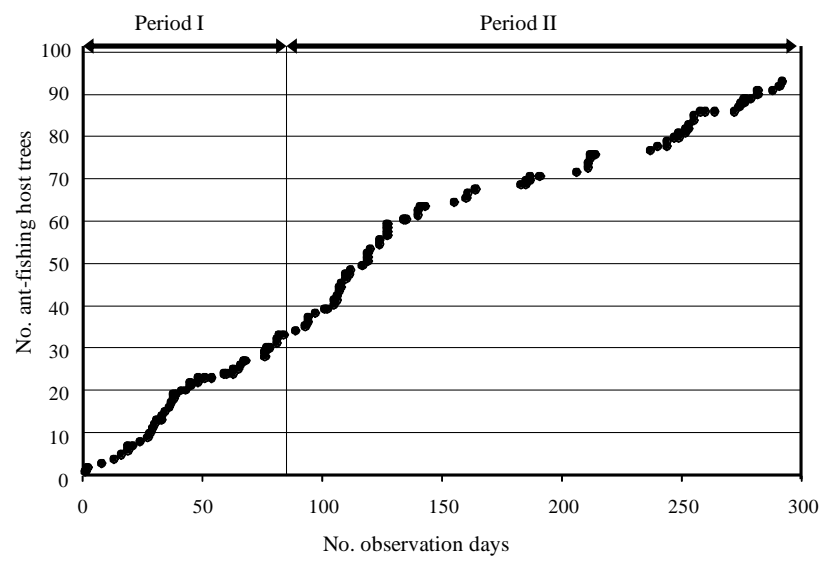

Fig. 2 The number of host trees used for ant-fishing increased with the number of observation days 
Natural history of Camponotus ant-fishing by Mahale chimpanzees

Table 4 Monthly number of ant-fishing sessions, participants in ant-fishing, focal observation hours, focal observation days, and cumulative number of chimpanzees observed in each month

\begin{tabular}{|c|c|c|c|c|c|c|c|c|c|c|c|c|}
\hline & \multicolumn{2}{|l|}{2003} & \multicolumn{9}{|l|}{2004} & \multirow[t]{2}{*}{ Total } \\
\hline & Nov & Dec & Jan & $\mathrm{Feb}$ & Mar & Apr & May & Jun & Jul & Aug & Sep & \\
\hline $\begin{array}{l}\text { (a) No. of ant-fishing sessions } \\
\text { observed }\end{array}$ & 6 & 22 & 11 & 4 & 5 & 1 & 7 & 0 & 5 & 14 & 15 & 90 \\
\hline $\begin{array}{l}\text { (b) No. of participants in } \\
\text { ant-fishing }\end{array}$ & 27 & 65 & 33 & 8 & 20 & 3 & 22 & 0 & 12 & 42 & 51 & 283 \\
\hline $\begin{array}{l}\text { (c) Mean no. of participants } \\
\text { per session (b/a) }\end{array}$ & 4.50 & 2.95 & 3.00 & 2.00 & 4.00 & 3.00 & 3.14 & - & 2.40 & 3.00 & 3.40 & 3.14 \\
\hline (d) Total observation time (h) & 137.30 & 194.65 & 193.72 & 113.99 & 166.25 & 66.71 & 95.18 & 34.46 & 143.00 & 236.84 & 163.82 & 1545.92 \\
\hline (e) No. of observation days & 18 & 25 & 25 & 15 & 24 & 13 & 15 & 9 & 21 & 26 & 19 & 210 \\
\hline $\begin{array}{l}\text { (f) Cumulative no. of } \\
\text { chimpanzees observed }^{\mathrm{a}}\end{array}$ & 509 & 612 & 496 & 209 & 344 & 155 & 235 & 159 & 371 & 637 & 637 & 4364 \\
\hline (g) Mean nomadic party size ${ }^{\mathrm{b}}$ & 28.17 & 20.87 & 11.76 & 8.23 & 12.53 & 8.72 & 11.62 & 9.79 & 13.14 & 19.42 & 32.96 & 15.96 \\
\hline (h) Rainfall (mm) & 223.4 & 269.4 & 354.7 & 237.6 & 166.5 & 243.5 & 0.0 & 0.0 & 0.0 & 0.2 & 45.6 & 1540.9 \\
\hline
\end{tabular}

${ }^{a}$ Numbers of adult and adolescent chimpanzees counted on each observation day were accumulated throughout each month

${ }^{\mathrm{b}}$ The definition of nomadic party follows Itoh and Nishida (2007)

Table 5 Frequency of ant-fishing in each season

\begin{tabular}{llllll}
\hline Seasons & $\begin{array}{l}\text { Early wet } \\
\text { (Nov 2003-Jan } \\
\text { 2004) }\end{array}$ & $\begin{array}{l}\text { Late wet } \\
\text { (Feb-Apr } \\
\text { 2004) }\end{array}$ & $\begin{array}{l}\text { Early dry } \\
\text { (May-Jul } \\
2004)\end{array}$ & $\begin{array}{l}\text { Late dry } \\
\text { (Aug-Sep } \\
\text { 2004) }\end{array}$ & Total \\
\hline (a) Rainfall (mm) & 847.5 & 647.6 & 0.0 & 45.8 & 1540.9 \\
(b) No. of observation days & 68 & 52 & 45 & 45 & 210 \\
(c) Total observation time (h) & 525.67 & 346.95 & 272.64 & 400.66 & 1545.92 \\
(d) Cumulative no. of chimpanzees observed ${ }^{\mathrm{a}}$ & 1617 & 708 & 765 & 1274 & 4364 \\
(e) Mean nomadic party size & 18.40 & 9.89 & 11.88 & 25.34 & 15.96 \\
(f) No. of ant-fishing sessions & 39 & 10 & 12 & 29 & 90 \\
$\quad$ expected values $^{\mathrm{b}}$ & 33.35 & 14.60 & 15.78 & 26.27 & $\chi^{2}=3.60, d f=3, p=0.31$ \\
(g) No. of participants in ant-fishing & 125 & 31 & 34 & 93 & 283 \\
$\quad$ expected values $^{\mathrm{b}}$ & 104.86 & 45.91 & 49.61 & 82.62 & $\chi^{2}=14.93, d f=3, p<0.01$ \\
(h) Mean no. of participants per session (g/f) & 3.21 & 3.10 & 2.83 & 3.21 & 3.14 \\
\hline
\end{tabular}

${ }^{a}$ Numbers of adult and adolescent chimpanzees counted on each observation day were accumulated throughout each season

${ }^{b}$ Expected values: total numbers were allocated to each season in proportion to the cumulative number of chimpanzees observed during the respective seasons (d)

\section{Seasonality of ant-fishing}

Ant-fishing was not constantly observed throughout a year among the $M$ group chimpanzees. Table 4 shows the monthly number of observed ant-fishing sessions and other factors presumably affecting them. In general, ant-fishing sessions were observed frequently from August to January (Table 4 item $a$ ); fewer chimpanzees were observed to engage in ant-fishing from February to July (Table 4 item $b$ ), yet differences were not clear. The mean number of participants per session was relatively constant throughout a year (Table 4 item $c$ ), although mean nomadic party size fluctuated seasonally (Table 4 item $g$; Itoh and Nishida 2007).

To evaluate the seasonality of ant-fishing correctly, one should exclude possible observational biases affecting the number of observed ant-fishing sessions in each month, such as total observation hours (Table 4 item $d$ ), total observation days (Table 4 item $e$ ), and cumulative number of chimpanzees observed in each month (Table 4 item $f$ ). As easily predicted, the monthly number of ant-fishing sessions was positively correlated with the monthly observation hours $(N=11, \tau=0.62, p<0.01)$, monthly observation days ( $\tau=0.60, p<0.05$ ), and monthly cumulative number of chimpanzees observed on each observation day $(\tau=0.77, p$ $<0.01)$. These results indicate that the $\mathrm{M}$ group chimpanzees obtain ants with tools constantly throughout a year; that is, the longer the observation duration and the greater the number of chimpanzees one would observe, the more ant-fishing sessions would be observed in general. 
To conduct further analyses, I pooled these data into 4 seasons by rainfall pattern (Table 5; cf. Matsumoto-Oda 2002). The observed number of ant-fishing sessions did not differ significantly among seasons (Table 5 item $f ; \chi^{2}=3.60$, $d f=3, p=0.31$ ), again indicating that the $\mathbf{M}$ group chimpanzees fish for ants with tools constantly throughout a year. On the other hand, the number of participants in ant-fishing sessions differed significantly among seasons (Table 5 item $g ; \chi^{2}=14.93, d f=3, p<0.01$ ); more chimpanzees participated in ant-fishing in the early wet and late dry seasons, and fewer participated in the late wet and early dry seasons, than expected from the observed number of chimpanzees. This difference might have been caused by the seasonal variation in the mean nomadic party size (Table 5 item $e$ ).

\section{Number of Camponotus ants consumed}

The number of ants preyed upon by chimpanzees was determined in 18 ant-fishing bouts. On average, 15.7 ants were consumed per minute (overall, 4796 ants were counted in ca. $305.18 \mathrm{~min}$ ); that is, 389.0 ants were consumed in an average bout duration of $24.75 \mathrm{~min}$ (see below). In the most efficient bout, an adult female consumed 253 ants in $10 \mathrm{~min}$ (25.3 ants per minute). During the longest ant-count at host tree \#7 on August 29, 2002, an adult female (FT) consumed 3157 ants in $2.88 \mathrm{~h}$ (18.3 ants per minute; Fig. 3). In this case, she consumed ants fairly constantly throughout the bout, except for intervals during which she renewed tools or temporarily suspended ant-fishing. This indicates that the ant biomass was superabundant despite predation by the chimpanzees. Indeed, this host tree \#7 was used on August 27, 2002 ( 2 days before this case) by 5 chimpanzees for about $1.8 \mathrm{~h}$, and again on September 8, 2002 (10 days after this case) by 15 chimpanzees for about $2.3 \mathrm{~h}$, and the productivity of the tree as an ant-fishing site did not seem to have decreased between these sessions.

Figure 4 shows the number of ants consumed per minute plotted against the age of the chimpanzee preying upon ants in each bout. Although the correlation was not significant $(N$ $=18, \tau=0.19, p=0.27$ ), and nor was the difference in ant-fishing efficiency among age classes $(H=3.18, d f=3, p$ $=0.36$, Kruskal-Wallis test), the variance of ant-fishing efficiency tended to increase as chimpanzees got older. It is also notable that even mature chimpanzees do not always fish for ants more efficiently than youngsters.

Figure 5 shows the number of ants consumed per minute at each host tree. The efficiency of ant-fishing varied even at the same host tree. The ant-fishing efficiency at the same host tree varied not only between sessions but also between individuals within a session. For instance, at host tree \#7 on September 8, 2002, an old female (GW), who was the first participant in the ant-fishing session, consumed ants at very low efficiency (ca. 2.2 ants per minute). On the other hand, subsequent participants (including juveniles) consumed ants with much higher efficiency (ca. 10.1-10.7 ants per minute). It seems that the productivity of each host tree, i.e., the availability of ants at each host tree, varied not only among individual trees, but also among sessions and bouts even at the same single tree. These results indicate that the efficiency of ant-fishing is not simply determined by whether or not a chimpanzee is skilled or by site choice, but it inevitably depends on the unpredictable ant availability.

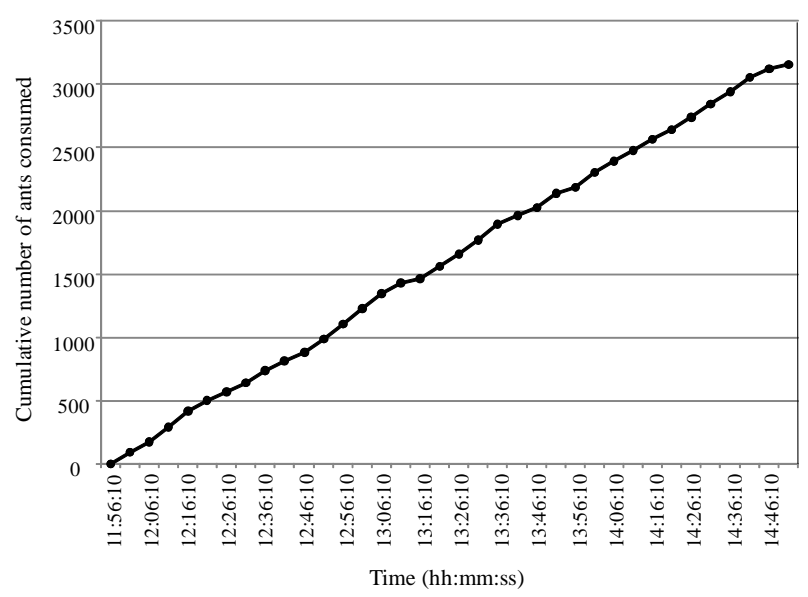

Fig. 3 Efficiency of ant-fishing by an adult female (FT) at tree \#7 on August 29, 2002 (11:56:10-14:48:40 hh:mm:ss; 3157 ants consumed in total)

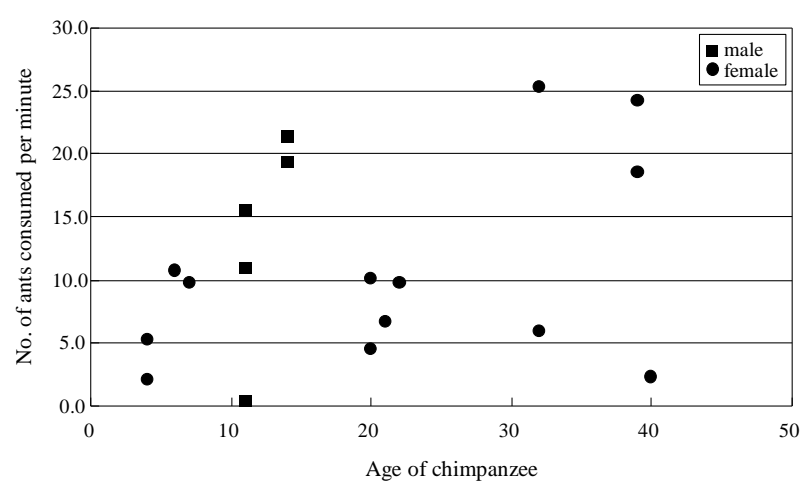

Fig. 4 Relation between the number of ants consumed per minute and the age of the chimpanzees fishing for ants (Kendall's rank correlation: $N=18, \tau=0.19, p=0.27$; Kruskal-Wallis test for differences among age classes: $H=3.18, d f=3, p=0.36$ )

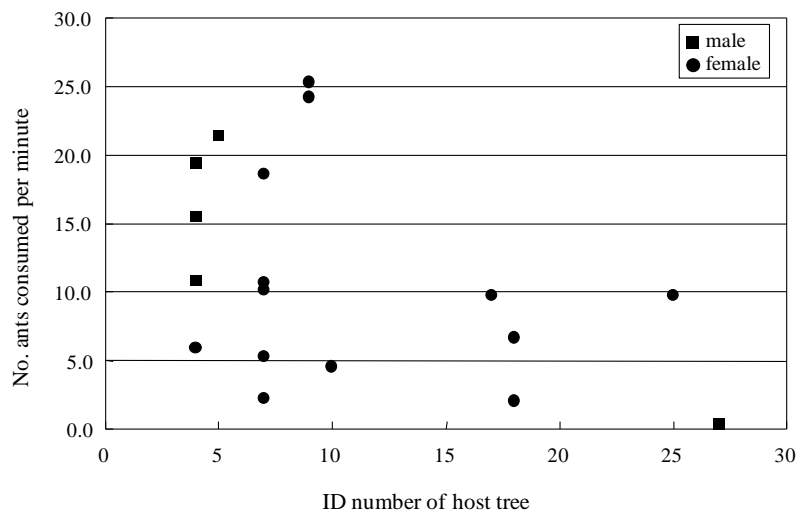

Fig. 5 Number of ants consumed per minute at each host tree of ants 


\section{Ant-fishing participants}

Among the 60 members of the $M$ group chimpanzees, 50 $(83.3 \%)$ were observed to successfully fish for Camponotus ants with probes by the end of Period II (Table 6). Except for a 6-year-old juvenile male, all juveniles, adolescents, and adults were observed to fish for ants with tools. Infants older than 3 years ( 1 male and 2 females) were also observed to fish for ants with tools. Only 1 female infant younger than 3 years was successful in ant-fishing (2.4 years at the first observation of successful ant-fishing). Another 9 infants younger than 3 years were not observed to fish for ants successfully, though they occasionally showed trial-like sequences such as biting off vines or leaves and inserting them into holes on the surface of trees without obtaining ants.

Table 6 Age/sex class composition of the M group chimpanzees fishing for ants

\begin{tabular}{|c|c|c|}
\hline Age/sex class & $\begin{array}{l}\text { No. of } \\
\text { individuals }\end{array}$ & $\begin{array}{l}\text { No. of ant-fishing } \\
\text { individuals }(\%)^{\mathrm{b}}\end{array}$ \\
\hline \multicolumn{3}{|l|}{ [Male] } \\
\hline Adult $(16$ years $<$ ) & 7 & $7(100)$ \\
\hline Adolescent (9-15 years) & 5 & $5(100)$ \\
\hline Juvenile (5-8 years) & 3 & $2(66.7)$ \\
\hline Infant $(0-4$ years $)$ & 6 & $1(16.7)$ \\
\hline Total (Male) & 21 & 15 (71.4) \\
\hline
\end{tabular}

\section{[Female]}

\begin{tabular}{|c|c|c|}
\hline Adult $(13$ years $<)$ & 22 & $22(100)$ \\
\hline Adolescent (9-12 years) & 2 & $2(100)$ \\
\hline Juvenile (5-8 years) & 8 & $8(100)$ \\
\hline Infant ( $0-4$ years $)$ & 7 & $3(42.9)$ \\
\hline Total (Female) & 39 & $35(89.7)$ \\
\hline Total (All) & 60 & $50(83.3)$ \\
\hline
\end{tabular}

\section{Frequency of ant-fishing}

Over the course of the study, I observed 140 ant-fishing sessions during 2180.01 observation hours (0.64 sessions per $10 \mathrm{~h}$ or once per $15.57 \mathrm{~h}$ ). During $1780.09 \mathrm{~h}$ of focal follows, I observed 99 ant-fishing sessions (0.56 sessions per $10 \mathrm{~h}$ or once per $17.98 \mathrm{~h}$ ).

The accumulated number of participants in ant-fishing in each age/sex class is summarized in Table 7. Overall, the number of participants in ant-fishing differed significantly between the sexes $\left(\chi^{2}=10.47, d f=1, p<0.01\right)$. Infants of both sexes tended to participate in ant-fishing less frequently. On average, adult males engaged in ant-fishing less frequently than all other age/sex classes.

In a detailed comparison, the number of participation in ant-fishing differed significantly among age/sex classes (Fig. 6; $H=22.62, d f=7, p<0.01$, Kruskal-Wallis test), and a significant difference was found only between adult males and adult females $(W=161.5$, adjusted $p$ value $<0.05$, multiple pairwise comparisons by Wilcoxon rank-sum test with Holm's method).

A similar sex difference in ant-fishing frequency was found in the focal following data (Table 8); females fished for ants 5 times as often as males did ( 0.31 for females vs 0.06 for males per 10 focal following hours,). This difference was also statistically significant $\left(\chi^{2}=11.07, d f=\right.$ $1, p<0.001)$.

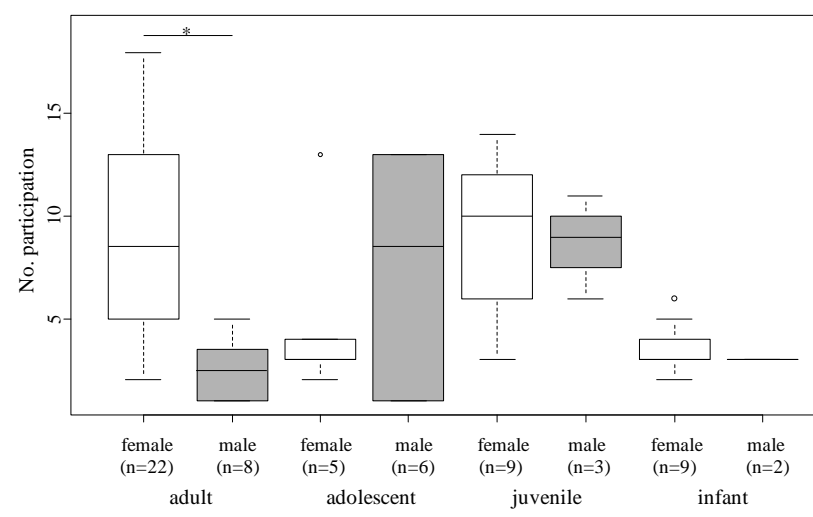

Fig. 6 Number of participation in ant-fishing in each age/sex class of chimpanzees (Kruskal-Wallis test: $H=22.62, d f=7, p<0.01$; *multiple pairwise comparisons by Wilcoxon rank-sum test with Holm's method: $W=161.5$, adjusted $p$ value $<0.05$ )

\section{Duration of ant-fishing bout}

Ant-fishing bout-lengths in each age/sex class are summarized in Table 7. Overall, the mean bout-length was $24.75 \mathrm{~min}$ ( 220 bouts; total bout-length $5445.75 \mathrm{~min}$ ) and the median bout-length was $14.27 \mathrm{~min}$. Females fished for ants for significantly longer than males did $(W=5556, p<$ 0.05 , Wilcoxon rank-sum test). No statistically significant difference was found among age classes $(H=2.95, d f=3, p$ $=0.40$, Kruskal-Wallis test $)$.

The focal following data of ant-fishing indicated similar sex differences: females fished for ants for 8 times as long as males did (Table $8 ; 2.13$ and $0.26 \%$ of focal observation times, respectively). The difference in total bout-lengths during focal following for each sex was statistically significant $\left(\chi^{2}=9.57, d f=1, p<0.01\right)$.

Bout-length was not correlated with the number of participants in ant-fishing sessions $(N=220, \tau=0.02, p=$ 0.65 ), indicating that chimpanzees engaged in ant-fishing for a fairly constant period of time regardless of the number of other participants in the same ant-fishing session. This implies that contest competition has little effect on ant-fishing among chimpanzees. 
Natural history of Camponotus ant-fishing by Mahale chimpanzees

Table 7 Frequency and bout-length of ant-fishing in each age/sex class

\begin{tabular}{|c|c|c|c|c|c|c|c|}
\hline \multirow{2}{*}{ Age/sex class } & \multirow{2}{*}{$\begin{array}{l}\text { No. of } \\
\text { individuals }^{\mathrm{a}}\end{array}$} & \multirow{2}{*}{$\begin{array}{l}\text { No. of } \\
\text { participants }^{b}\end{array}$} & \multirow{2}{*}{$\begin{array}{l}\text { Frequency } \\
{\text { (range })^{\mathrm{d}}}^{\mathrm{c}}\end{array}$} & \multirow{2}{*}{$\begin{array}{l}\text { No. of complete } \\
\text { observed bouts }\end{array}$} & \multicolumn{3}{|c|}{ Bout-length (min) } \\
\hline & & & & & Total & Median & Range \\
\hline \multicolumn{8}{|l|}{ [Male] } \\
\hline Adult (16 years <) & 8 & 20 & $2.5(1-5)$ & 12 & 196.10 & 8.28 & $0.68-65.75$ \\
\hline Adolescent (9-15 years) & 6 & 45 & $7.5(1-13)$ & 27 & 509.57 & 14.98 & $0.23-50.10$ \\
\hline Juvenile (5-8 years) & 3 & 26 & $8.7(6-11)$ & 16 & 261.50 & 6.26 & $0.40-79.25$ \\
\hline Infant $(0-4$ years $)$ & 2 & 6 & $3.0(3-3)$ & 2 & 49.25 & 24.63 & $2.50-46.75$ \\
\hline Total (Male) & 19 & $97(127.66)^{\mathrm{e}}$ & $5.1(1-13)$ & 57 & 1016.42 & 10.83 & $0.23-79.25$ \\
\hline \multicolumn{8}{|l|}{ [Female] } \\
\hline Adult (13 years <) & 22 & 194 & $8.8(2-18)$ & 94 & 2762.20 & 15.61 & $0.55-172.50$ \\
\hline Adolescent (9-12 years) & 5 & 25 & $5.0(2-13)$ & 12 & 366.62 & 23.60 & $1.92-109.75$ \\
\hline Juvenile (5-8 years) & 9 & 82 & $9.1(3-14)$ & 42 & 883.63 & 16.05 & $0.43-92.95$ \\
\hline Infant $(0-4$ years $)$ & 9 & 32 & $3.6(2-6)$ & 15 & 416.90 & 8.65 & $1.17-108.50$ \\
\hline Total (Female) & 45 & $333(302.34)^{\mathrm{e}}$ & $7.4(2-18)$ & 163 & 4429.35 & 15.78 & $0.43-172.50$ \\
\hline Total (All) & 64 & 430 & $6.7(1-18)$ & 220 & 5445.77 & 14.27 & $0.23-172.50$ \\
\hline
\end{tabular}

${ }^{\mathrm{a}}$ Number of the $\mathrm{M}$ group members observed to fish for ants in either or both periods

${ }^{\mathrm{b}}$ Cumulative number of chimpanzees observed to fish for ants with tools during the study periods. One individual was counted only once on each ant-fishing session. The age class was applied to each individual at the time of each ant-fishing observation

${ }^{c}$ Cumulative number of participants (b) divided by the number of individuals per age class (a)

${ }^{\mathrm{d}}$ Range of the number of participation in ant-fishing by each chimpanzee during the 2 study periods

${ }^{\mathrm{e}}$ Expected values: total number of participants were allocated to each sex in proportion to the number of individuals (a)

Table 8 Frequency and duration of ant-fishing per focal target

\begin{tabular}{|c|c|c|c|c|c|c|}
\hline Focal individual $^{\mathrm{a}}$ & $\begin{array}{l}\text { Focal observation } \\
\text { time }(\mathrm{h})\end{array}$ & $\begin{array}{l}\text { No. of bouts } \\
\text { during focal } \\
\text { observation }\end{array}$ & $\begin{array}{l}\text { No. of bouts per } \\
10 \text { focal } \\
\text { observation hours }\end{array}$ & $\begin{array}{l}\text { Total bout-length } \\
\text { during focal } \\
\text { observation ( } \mathrm{min} \text { ) }\end{array}$ & $\begin{array}{l}\text { Mean bout-length } \\
\text { (min) }\end{array}$ & $\begin{array}{l}\text { Rate of } \\
\text { ant-fishing (\%) }\end{array}$ \\
\hline & $\mathrm{A}$ & $\mathrm{B}$ & $10 \times \mathrm{B} / \mathrm{A}$ & $\mathrm{C}$ & $\mathrm{C} / \mathrm{B}$ & $\mathrm{C} /(60 \times \mathrm{A})$ \\
\hline \multicolumn{7}{|l|}{ [Male] } \\
\hline AL (adult) & 221.00 & 1 & 0.05 & 21.48 & 21.48 & $0.16 \%$ \\
\hline DE (adult) & 151.62 & 0 & 0.00 & - & - & - \\
\hline FN (adult) & 115.29 & 0 & 0.00 & - & - & - \\
\hline OR (adolescent) & 32.92 & 2 & 0.61 & 11.58 & 5.79 & $0.59 \%$ \\
\hline Others & 104.04 & 1. & 0.10 & 65.75 & 65.75 & $1.05 \%$ \\
\hline Total (Male) & 624.87 & $4(14.04)^{\mathrm{b}}$ & 0.06 & $98.82(552.43)^{\mathrm{b}}$ & 24.70 & $0.26 \%$ \\
\hline \multicolumn{7}{|l|}{ [Female] } \\
\hline GW (adult) & 49.89 & 1 & 0.20 & 13.75 & 13.75 & $0.46 \%$ \\
\hline FT (adult) & 152.83 & 6 & 0.39 & 355.20 & 59.20 & $3.87 \%$ \\
\hline IK (adult) & 40.47 & 0 & 0.00 & - & - & - \\
\hline OP (adult) & 140.90 & 2 & 0.14 & 9.28 & 4.64 & $0.11 \%$ \\
\hline XT (adult) & 38.45 & 1 & 0.26 & 37.62 & 37.62 & $1.63 \%$ \\
\hline MJ (adult) & 104.25 & 3 & 0.29 & 229.02 & 76.34 & $3.66 \%$ \\
\hline AK (adult) & 48.70 & 4 & 0.82 & 220.18 & 55.05 & $7.54 \%$ \\
\hline CY (adult) & 30.10 & 0 & 0.00 & - & - & - \\
\hline $\mathrm{AB}$ (adult) & 64.97 & 1 & 0.15 & 60.78 & 60.78 & $1.56 \%$ \\
\hline TZ (adult) & 166.47 & 6 & 0.36 & 239.60 & 39.93 & $2.40 \%$ \\
\hline RB (adult) & 118.62 & 3 & 0.25 & 102.70 & 34.23 & $1.44 \%$ \\
\hline Others & 199.58 & 9 & 0.45 & 206.78 & 22.98 & $1.73 \%$ \\
\hline Total (Female) & 1155.22 & $36(25.96)^{\mathrm{b}}$ & 0.31 & $1474.92(1021.30)^{\mathrm{b}}$ & 40.97 & $2.13 \%$ \\
\hline Total (All) & 1780.09 & 40 & 0.22 & 1573.73 & 39.34 & $1.47 \%$ \\
\hline
\end{tabular}

${ }^{a}$ Focal individuals followed for longer than $30 \mathrm{~h}$ are listed along with their names

${ }^{\mathrm{b}}$ Expected values: total number of bouts (total bout-length) were allocated to each sex in proportion to the focal observation time (A) 


\section{Discussion}

\section{Ecological context of ant-fishing}

Two species of Camponotus ants (C. sp.1 and C. brutus) were identified as the target species of ant-fishing by the M group chimpanzees, $C$. sp. 1 being the main target. $C$. sp.1 ants were distributed widely, at least over the western/ lowland region, in the $M$ group's home range and dwelled in a wide variety of tree species. Their biomass appeared to be superabundant as compared to the predation by the chimpanzees.

Twenty-four species of trees were identified as ant-fishing sites, of which the top 5 species were used frequently and repeatedly. The following factors, though not mutually exclusive, are thought to affect this biased use of some tree species as ant-fishing sites: (1) the chimpanzees' knowledge about the species of trees in which the target ants dwell; (2) factors irrelevant to the distribution of ants, such as the ease of posture during ant-fishing; and (3) the preferences of the ants for some tree species. Based on some observations that chimpanzees obtained no ants despite their effort to fish for ants, it is unlikely that chimpanzees have complete knowledge of ant ecology. It is more likely that Camponotus ants dwell in a wide variety of tree species and that chimpanzees select trees opportunistically without complete knowledge of the ants' habitat. Nevertheless, chimpanzees might also partially utilize their former experiences about the location of ant-dwelling trees, as described in the result of repeated use of trees for ant-fishing (Fig. 1; Table 3). Further study on the distribution of Camponotus ants over the $\mathrm{M}$ group's home range remains to be made.

The calorie intake from Camponotus ants seems negligible. The $\mathrm{M}$ group chimpanzees do not increase ant-fishing in the late wet and early dry seasons when major fruit availability is relatively low at Mahale (Itoh 2004). This is different from the nut-cracking behavior of Bossou chimpanzees, which compensates for the scarcity of fruits (Yamakoshi 1998).

Another possibility is that chimpanzees obtain other nutrients, such as minerals, from the ants. To evaluate the nutritional value of the $C$. sp. 1 ants consumed by the M group chimpanzees, I used the available nutritional data of Camponotus brutus (Deblauwe and Janssens 2008) and of Camponotus vividus (Nishida and Hiraiwa 1982) as a basis. In an average bout (24.75 min), 389.0 heads of $C$. sp.1 ants were consumed, which are estimated to weigh $12.97 \mathrm{~g}$ based on the $C$. vividus data (Nishida and Hiraiwa 1982; 300 fresh C. vividus ants were estimated to weigh $10 \mathrm{~g})$. This amount of ants is estimated to have the nutritional composition shown in Table 9. The estimated intake of each nutrient per day obtained from ant-fishing is markedly lower than the estimated recommended intake. Thus, the nutritional value of ants appears to be negligible, and ant-fishing among the $M$ group chimpanzees is likely to be a 'leisure' activity (cf. Nishida 1973; Uehara 1986) rather than a subsistence activity (cf. Kawanaka 1990: ant-eating without tools).
Table 9 The average nutrient intake through ant-fishing, and estimated recommended intakes (ERI)

\begin{tabular}{|c|c|c|c|}
\hline & $\begin{array}{l}\text { Average } \\
\text { intake/bout }^{\mathrm{a}}\end{array}$ & $\begin{array}{l}\text { Average } \\
\text { intake/day }^{\mathrm{b}}\end{array}$ & $\mathrm{ERI}^{\mathrm{c}}$ \\
\hline Fresh matter $(\mathrm{g})$ & 12.97 & 2.91 & - \\
\hline Gross energy (kcal) & 15.56 & 3.50 & $2080-1762$ \\
\hline Dry matter $(\mathrm{g})$ & 2.98 & 0.67 & - \\
\hline Crude ash (g) & 0.12 & 0.03 & - \\
\hline Crude fat (g) & 0.12 & 0.03 & - \\
\hline Crude protein $(\mathrm{g})$ & 2.03 & 0.46 & - \\
\hline Acid detergent fiber $(\mathrm{g})$ & 0.39 & 0.09 & $38-25$ \\
\hline Real protein $(\mathrm{g})$ & 1.88 & 0.42 & $56-46$ \\
\hline $\mathrm{Na}(\mathrm{mg})$ & 1.19 & 0.27 & $1500-1500$ \\
\hline $\mathrm{K}(\mathrm{mg})$ & 14.32 & 3.22 & $4700-4700$ \\
\hline $\mathrm{Ca}(\mathrm{mg})$ & 9.25 & 2.08 & $1000-1000$ \\
\hline $\operatorname{Mg}(\mathrm{mg})$ & 5.07 & 1.14 & $415-315$ \\
\hline $\mathrm{P}(\mathrm{mg})$ & 25.05 & 5.63 & $700-700$ \\
\hline $\mathrm{S}(\mathrm{mg})$ & 0.92 & 0.21 & - \\
\hline $\mathrm{Fe}(\mathrm{mg})$ & 1.37 & 0.31 & $8-18$ \\
\hline $\mathrm{Zn}(\mathrm{mg})$ & 0.46 & 0.10 & $11-8$ \\
\hline $\mathrm{Mn}(\mathrm{mg})$ & 0.95 & 0.21 & $2.3-1.8$ \\
\hline $\mathrm{Cu}(\mu \mathrm{g})$ & 53.68 & 12.06 & $900-900$ \\
\hline
\end{tabular}

${ }^{a}$ The average intake per bout was estimated from the number of ants consumed in an average bout (389.0 ants/24.75 $\mathrm{min}$ ) and the nutritional data of $C$. brutus from Deblauwe and Janssens (2008). For example, 389.0 heads of $C$. sp.1 ants were estimated to weigh $12.97 \mathrm{~g}$ based on the $C$. vividus data from Nishida and Hiraiwa (1982) (300 fresh $C$. vividus were estimated to weigh $10 \mathrm{~g}$ ). $C$. sp.1 ants are estimated to contain $23 \%$ dry matter and $0.04 \% \mathrm{Na}$ on a dry matter basis (Deblauwe and Janssens 2008; C. brutus). Therefore, an estimated $1.19 \mathrm{mg}$ of $\mathrm{Na}$ is consumed in an average bout $(12.97 \mathrm{~g} \times 0.23 \times 0.0004=1.19 \mathrm{mg})$

$\mathrm{b}$ The average intake per day was estimated based on the frequency of ant-fishing bouts per 10 focal following hours $(0.22$ bouts $/ 10 \mathrm{~h})$

${ }^{c}$ The recommended intake for adult humans between 19 and 50 years old (male-female) (Institute of Medicine [IOM] 2011) was used as a guideline for the estimated recommended intake (ERI) for chimpanzees. The ERI of energy was based on the estimated energy requirements for sedentary humans of 30 years of age with a height of $1.5 \mathrm{~m}$ and a body mass index of $25 \mathrm{~kg} / \mathrm{m}^{2}$ (male-female). The ERI of acid detergent fiber corresponds to the recommended intake of total fiber for humans

\section{Age/sex differences of ant-fishing participants}

All the M group chimpanzees older than 3 years, except for 1 juvenile male, were found to fish for Camponotus ants with tools. This indicates that, by that age, most chimpanzees have acquired all the behavioral elements necessary for ant-fishing (e.g., identifying a tree hole, making tools, manipulating tools, and extracting ants). Although the details of the learning process could not be followed during the course of this study, distinct sex differences in tool-use acquisition (Lonsdorf 2005) were not found in ant-fishing. This might be due to: (1) the small number of male infants and juveniles in the $M$ group in comparison to females during the study periods; and (2) the short study period, which hindered the conduct of a longitudinal survey to follow the developmental process. 
Overall, the analyses performed in this study indicate clear sex differences, particularly among adults, in the frequency and duration of ant-fishing: females participated in ant-fishing more frequently and for longer durations than males. This is consistent with results from previous studies on insect eating with tools (termite-fishing: McGrew 1979; ant-fishing: Uehara 1986). McGrew (1979) suggested that the sex difference in termite-fishing among Gombe chimpanzees represented a counterbalance of nutrients gained from the insects (female) versus hunting (males) (nutritional hypothesis). Nishida and Hiraiwa (1982) and Uehara (1986) proposed an alternative hypothesis that states that Mahale chimpanzees fish for Camponotus ants seeking for formic acid as a kind of spice or snack (non-nutritional hypothesis). If we take into account the low nutritional value of ants as described above, the latter non-nutritional interpretation may be applicable to Camponotus ant-fishing among the $\mathrm{M}$ group chimpanzees. There is also a possibility that even similar tool-using insectivorous behaviors may have different meanings, such as subsistence termite-fishing and leisure (non-nutritional) Camponotus ant-fishing. The factors affecting the sex differences in ant-fishing may be clarified by further analyses both of the social interactions at and around ant-fishing sites (Hirata and Celli 2003; Lonsdorf 2006; Nishie 2008, 2010), and of the developmental processes (Hiraiwa-Hasegawa 1989; Lonsdorf 2005).

\section{Comparison of ant-fishing among chimpanzee groups and populations}

It is assumed that $C$. sp.1, the main target of ant-fishing among the $\mathrm{M}$ group chimpanzees, is identical to $C$. vividus described by Nishida and Hiraiwa (1982). This assumption is supported by the following findings: (1) the body design of $C$. vividus described by Nishida and Hiraiwa (1982) is similar to that of $C$. sp. 1 in the present study. In general, identification of the species within the genus Camponotus is quite difficult and complicated even for entomologists. For example, a cotype of Camponotus chrysurus apellis was mislabeled Camponotus vividus F. Smith, 1858 (Taylor 2010). I suspect that Nishida and Hiraiwa (1982) might have misidentified their specimens because of the difficulty of identification as above when they identified their specimens by themselves (Nishida, personal communication); (2) the abundance and the distribution of $C$. vividus are similar to those of $C$. sp.1. The northern part of the M group's home range overlaps with a large part of the former K group's home range studied by Nishida and Hiraiwa (1982) (see also Nishida 1990). Besides, it appears that prey ant species fished by the chimpanzees in Gashaka ( $C$. chrysurus) (Fowler and Sommer 2007) are similar to the $C$. sp.1 (chrysurus-complex) in the present study (Taylor 2010). These assumptions imply that prey species selection in ant-fishing is at least partly consistent among different groups of chimpanzees, even between different subspecies [i.e., P. t. schweinfurthii and P. t. vellerosus (ellioti)], though further detailed comparison of the ants' ecology at different sites needs to be made in future studies.

C. brutus, the minor target of ant-fishing by the $\mathrm{M}$ group chimpanzees, was reported to be preyed upon with tools by the chimpanzees of the former K group (Nishida and Hiraiwa 1982) and the $Y$ group, the current neighboring group of the $\mathrm{M}$ group at Mahale (Sakamaki et al. 2007), in Lopé (Tutin and Fernandez 1992; Tutin et al. 1995), and Bossou (Yamamoto et al. 2008). These facts suggest that $C$. brutus is a common prey species among various wild chimpanzee populations, although the degree of concentration on the species as the target of ant-fishing may differ. At the same time, there might be variation in main prey species selection of Camponotus ant-fishing even between the neighboring groups at Mahale (i.e., M group: C. sp.1, Y group: C. brutus; present study; Sakamaki et al. 2007).

C. maculatus, the third target species of the K group's ant-fishing noted by Nishida and Hiraiwa (1982), was absent in the present study. This might be explicable partly by the ecological settings that both groups of chimpanzees inhabited. Nishida and Hiraiwa (1982) described that $C$. maculatus often made their nests in the trunks of Brachystegia trees. However, there are not as many Brachystegia trees in the M group's home range as those in the former $\mathrm{K}$ group's. Further, the M group chimpanzees did not select any Brachystegia trees as ant-fishing sites (Table 3). This tree species selection by chimpanzees and/or ants might explain the lack of $C$. maculatus in the present study.

These issues need further studies both from the aspect of the ecological conditions, including the characteristics of the prey ants (cf. Möbius et al. 2009; Schöning et al. 2008), and the social context (cf. Humle et al. 2009).

The frequency of ant-fishing sessions by the $\mathrm{M}$ group shown in this study $(0.64$ sessions/10 h) was higher than that shown by the $\mathrm{K}$ group $(0.36$ sessions $/ 10 \mathrm{~h}$; Nishida and Hiraiwa 1982). This difference may reflect a difference in the observational conditions, rather than an actual difference in ant-fishing occurrences. The data of the K group were collected in the 1970s, when habituation was in progress. Because male chimpanzees are generally habituated easier and sooner than females (Boesch-Achermann and Boesch 1994; Bertolani and Boesch 2008), the data of the $\mathrm{K}$ group might have been biased towards males. This could explain the less frequent ant-fishing sessions in the $\mathrm{K}$ group, because males are less-frequent ant-fishers than females, as illustrated in the present study.

The mean bout-length of ant-fishing by the $\mathbf{M}$ group (24.75 min) was a little shorter than that of the $\mathrm{K}$ group (33.2 min; Nishida and Hiraiwa 1982). This difference might have been derived from different methods of data processing, as Nishida and Hiraiwa (1982) included incomplete data when bouts continued for longer than 60 $\min$.

Therefore, ant-fishing in the $\mathrm{K}$ and the $\mathrm{M}$ groups at Mahale seems not to differ greatly with regard to the target species, frequency, or duration. There are no comparable data regarding age/sex differences in 
ant-fishing in the $\mathrm{K}$ group.

Currently, there are no comparable data on Camponotus ant-fishing from other chimpanzee study sites, except for a few descriptions of the target ant species. Detailed primary data of ant-fishing from other study sites are awaited in order to make wider comparisons, which will, it is hoped, help in illustrating the cultural aspects of ant-fishing among wild chimpanzees.

\section{Acknowledgements}

This study was financially supported by a MEXT Grant-in-Aid for Scientific Research (\#16255007 to T. Nishida and \#19107007 to J. Yamagiwa), and a Grant-in-Aid for 21st Century COE Research (A14). I thank the COSTECH, TAWIRI, and TANAPA for permissions to conduct the fieldwork; and MMWRC and MMNP for logistic support. I am grateful to T. Nishida, M. Nakamura, N. Itoh, and K. Zamma for their valuable advice and encouragement; H. Ihobe, $\mathrm{K}$ Ihobe, $\mathrm{M}$. Shimada, T. Nishida, M. Nakai, S. Uehara, K. Zamma, and M. Nakamura for their cooperation in the field. I am grateful to J. Yamagiwa and two anonymous referees for valuable comments on the manuscript. This field research could not have been completed without the help of field assistants: R. Kitopeni, M. Hamisi, R. Hawazi, M. Mwami, H. Bunengwa, K. Athumani, M. Matumla, B. Haruna, M. Makelele, and S. Kabangula. This article is dedicated to the memory of Professor Toshisada Nishida.

\section{References}

Alp R (1993) Meat eating and ant dipping by wild chimpanzees in Sierra Leone. Primates 34:463-468

Bermejo M, Illera G (1999) Tool-set for termite-fishing and honey extraction by wild chimpanzees in the Lossi Forest, Congo. Primates 40:619-627

Bermejo M, Illera G, Sabater Pi J (1989) New observations on the tool-behavior of chimpanzees from Mt. Assirik (Senegal, west Africa). Primates 30:65-73

Bertolani P, Boesch C (2008) Habituation of wild chimpanzees (Pan troglodytes) of the South Group at Taï Forest, Côte d'Ivoire: empirical measure of progress. Folia Primatol 79:162-171

Boesch C, Boesch H (1990) Tool use and tool making in wild chimpanzees. Folia Primatol 54:86-99

Boesch-Achermann H, Boesch C (1994) The Taï chimpanzee project in Côte d'Ivoire, West Africa. Pan Afr News 1:5-7

Bogart SL, Pruetz JD (2008) Ecological context of savanna chimpanzee (Pan troglodytes verus) termite fishing at Fongoli, Senegal. Am J Primatol 70:605-612

Bolton B (1995) A taxonomic and zoogeographical census of the extant ant taxa (Hymenoptera: Formicidae). J Nat Hist 29:1037-1056

Deblauwe I, Janssens GPJ (2008) New insights in insect prey choice by chimpanzees and gorillas in southeast Cameroon: the role of nutritional value. Am J Phys Anthropol $135: 42-55$

Deblauwe I, Guislain P, Dupain J, van Elasacker L (2006) Use of tool-set by Pan troglodytes troglodytes to obtain termites (Macrotermes) in the periphery of the Dja Biosphere Reserve, southeast Cameroon. Am J Primatol 68:1191-1196

Fay JM, Carroll RW (1994) Chimpanzee tool use for honey and termite extraction in Central Africa. Am J Primatol 34:309-317

Fowler A, Sommer V (2007) Subsistence technology of Nigerian chimpanzees. Int J Primatol 28:997-1023

Goodall J (1963) Feeding behaviour of wild chimpanzees: a preliminary report. Symp Zool Soc Lond 10:39-48

Goodall J (1986) The Chimpanzees of Gombe: Patterns of Behavior. Harvard University Press, Cambridge

Hashimoto C, Furuichi T, Tashiro Y (2000) Ant dipping and meat eating by wild chimpanzees in the Kalinzu Forest, Uganda. Primates 41:103-108

Hicks TC, Fouts RS, Fouts DH (2005) Chimpanzee (Pan troglodytes troglodytes) tool use in the Ngotto Forest, Central African Republic. Am J Primatol 65:221-237

Hiraiwa-Hasegawa M (1989) Sex differences in the behavioral development of chimpanzees at Mahale. In: Heltne PG, Marquardt LA (eds) Understanding Chimpanzees. Harvard University Press, Cambridge, pp 104-115

Hirata S, Celli ML (2003) Role of mothers in the acquisition of tool-use behaviors by captive infant chimpanzees. Anim Cogn 6:235-244

Humle $T$ (1999) New record of fishing for termites (Macrotermes) by the chimpanzees of Bossou (Pan troglodytes verus), Guinea. Pan Afr News 6:3-5

Humle T, Matsuzawa T (2002) Ant-dipping among the chimpanzees of Bossou, Guinea, and some comparisons with other sites. Am J Primatol 58:133-148

Humle T, Snowdon CT, Matsuzawa T (2009) Social influences on ant-dipping acquisition in the wild chimpanzees (Pan troglodytes verus) of Bossou, Guinea, West Africa. Anim Cogn 12(Suppl 1):S37-S48

Institute of Medicine (IOM) (2011) Dietary reference intakes tables and application. http://iom.edu/Home/Global/News\%20Announcements/DRI. Accessed 26 Feb 2011

Itoh N (2004) Plant phenology and chimpanzee fission-fusion grouping system in Mahale Mountains National Park. Ph.D. Dissertation, Kyoto University, Kyoto

Itoh N, Nishida T (2007) Chimpanzee grouping patterns and food availability in Mahale Mountains National Park, Tanzania. Primates 48:87-96

Jones C, Sabater Pi J (1969) Sticks used by chimpanzees in Rio Muni, West Africa. Nature 223:100-101

Kawanaka K (1990) Age differences in ant-eating by adult and adolescent males. In: Nishida $\mathrm{T}$ (ed) The Chimpanzees of the Mahale Mountains: Sexual and Life History Strategies. University of Tokyo Press, Tokyo, pp 207-222

Lonsdorf EV (2005) Sex differences in the development of termite-fishing skills in the wild chimpanzees, Pan troglodytes schweinfurthii, of Gombe National Park, Tanzania. Anim Behav 70:673-683

Lonsdorf EV (2006) What is the role of mothers in the acquisition of termite-fishing behaviors in wild chimpanzees (Pan troglodytes schweinfurthii)? Anim Cogn 9:36-46

Matsumoto-Oda A (2002) Behavioral seasonality in Mahale chimpanzees. Primates 43:103-117

McBeath NM, McGrew WC (1982) Tools used by wild chimpanzees to obtain termites at Mt Assirik, Senegal: the influence of habitat. J Hum Evol 11:65-72

McGrew WC (1974) Tool use by wild chimpanzees in feeding upon driver ants. J Hum Evol 3:501-508

McGrew WC (1979) Evolutionary implications of sex difference in chimpanzee predation and tool use. In: Hamburg DA, McCown ER (eds) The Great Apes. Benjamin/Cummings, Menlo Park, pp 440-463

McGrew WC (1983) Animal foods in the diets of wild chimpanzees (Pan troglodytes): why cross-cultural variation? J Ethol 1:46-61

McGrew WC (1992) Chimpanzee Material Culture: Implications for Human Evolution. Cambridge University Press, Cambridge

McGrew WC (2004) The Cultured Chimpanzee: Reflections on 
Cultural Primatology. Cambridge University Press, Cambridge

McGrew WC (2010) New theaters of conflict in the animal culture wars: recent findings from chimpanzees. In: Lonsdorf EV, Ross SR, Matsuzawa T (eds) The Mind of the Chimpanzee: Ecological and Experimental Perspectives. The University of Chicago Press, Chicago, pp 168-177

McGrew WC, Collins DA (1985) Tool use by wild chimpanzees (Pan troglodytes) to obtain termites (Macrotermes herus) in the Mahale Mountains, Tanzania. Am J Primatol 9:47-62

McGrew WC, Rogers ME (1983) Chimpanzees, tools, and termites: new record from Gabon. Am J Primatol 5:171-174

McGrew WC, Tutin CEG, Baldwin PJ (1979) Chimpanzees, tools, and termites: cross-cultural comparisons of Senegal, Tanzania, and Rio Muni. Man 14:185-214

McGrew WC, Marchant LF, Scott SE, Tutin CEG (2001) Intergroup differences in a social custom of wild chimpanzees: the grooming hand-clasp of the Mahale Mountains. Curr Anthropol 42:148-153

McGrew WC, Baldwin PJ, Marchant LF, Pruetz JD, Scott SE, Tutin CEG (2003) Ethoarchaelogy and elementary technology of unhabituated wild chimpanzees at Assirik, Senegal, West Africa. PaleoAnthropology 2003:1-20

McGrew WC, Pruetz JD, Fulton SJ (2005) Chimpanzees use tools to harvest social insects at Fongoli, Senegal. Folia Primatol 76(4):222-226

Möbius Y, Boesch C, Koops K, Matsuzawa T, Humle T (2009) Cultural differences in army ant predation by West African chimpanzees? A comparative study of microecological variables. Anim Behav 76:37-45

Muroyama Y (1991) Chimpanzees' choices of prey between two sympatric species of Macrotermes in the Campo Animal Reserve, Cameroon. Hum Evol 6:143-151

Nakamura M, Uehara S (2004) Proximate factors of different types of grooming-hand-clasp in Mahale chimpanzees: implications for chimpanzee social custom. Curr Anthropol 45:108-114

Nakamura M, Corp N, Fujimoto M, Fujita S, Hanamura S, Hayaki H, Hosaka K, Huffman MA, Inaba A, Inoue E, Itoh N, Kawanaka K, Kutsukake N, Kiyono-Fuse M, Kooriyama T, Marchant LF, Matsumoto-Oda A, Matsusaka T, McGrew WC, Mitani JC, Nishie H, Norikoshi K, Sakamaki T, Shimada M, Turner LA, Uehara S, Wakibara JV, Zamma K, Nishida T (2011) Home range of Mahale chimpanzees: from 16 years' data. Primate Res 27(Suppl):18-19 (in Japanese)

Nishida T (1973) The ant-gathering behaviour by the use of tools among wild chimpanzees of the Mahali Mountains. $J$ Hum Evol 2:357-370

Nishida T (ed) (1990) The Chimpanzees of the Mahale Mountains: Sexual and Life History Strategies. University of Tokyo Press, Tokyo

Nishida T, Hiraiwa M (1982) Natural history of a tool-using behavior by wild chimpanzees in feeding upon wood-boring ants. J Hum Evol 11:73-99

Nishida T, Uehara S (1980) Chimpanzees, tools, and termites: another example from Tanzania. Curr Anthropol 21:671-672

Nishida T, Hiraiwa-Hasegawa M, Hasegawa T, Takahata Y (1985) Group extinction and female transfer in wild chimpanzees in the Mahale National Park, Tanzania. Z Tierpsychol 67:284-301

Nishida T, Kano T, Goodall J, McGrew WC, Nakamura M (1999) Ethogram and ethnography of Mahale chimpanzees. Anthropol Sci 107:141-188

Nishida T, Corp N, Hamai M, Hasegawa T, Hiraiwa-Hasegawa $\mathrm{M}$, Hosaka K, Hunt $\mathrm{KD}$, Itoh $\mathrm{N}$, Kawanaka $\mathrm{K}$, Matsumoto-Oda A, Mitani JC, Nakamura M, Norikoshi K,
Sakamaki T, Tuner L, Uehara S, Zamma K (2003) Demography, female life history and reproductive profiles among the chimpanzees of Mahale. Am $J$ Primatol 59(3):99-121

Nishie H (2008) Chimpanzee culture and sociality: reconsidering 'the metaphor of transmission of knowledge'. Primate Res 24:73-90 (in Japanese with English summary)

Nishie H (2010) Never-ending interaction: 'redundant' interaction among wild chimpanzees. In: Kimura D, Nakamura M, Takanashi K (eds) Boundary and Conjunction of Social Interaction: Studies in Nonhuman Primates, Humans and Conversation. Showado, Kyoto, pp 387-396 (in Japanese)

O'Malley RC, Wallauer B, Murray CM (2010) Tool-assisted predation on Camponotus ants by Gombe chimpanzees. Primate Res 26(Suppl):337

Sabater Pi J (1974) An elementary industry of the chimpanzees in the Okorobikó Mountains, Rio Muni (Republic of Equatorial Guinea), west Africa. Primates 15:351-364

Sakamaki T, Nakamura M, Nishida T (2007) Evidence of cultural differences in diet between two neighboring unit groups of chimpanzees in Mahale Mountains National Park, Tanzania. Pan Afr News 14:3-5

Sanz C, Morgan D, Gulick S (2004) New insights into chimpanzees, tools, and termites from the Congo Basin. Am Nat 164:567-581

Schöning C, Humle T, Möbius Y, McGrew WC (2008) The nature of culture: technological variation in chimpanzee predation on army ants revisited. J Hum Evol 55:48-59

SugiyamaY (1985) The brush-stick of chimpanzees found in south-west Cameroon and their cultural characteristics. Primates 26:361-374

Sugiyama Y (1995) Tool-use for catching ants by chimpanzees at Bossou and Monts Nimba, west Africa. Primates 36:193-205

Sugiyama Y, Koman J (1979) Tool-using and -making behavior in wild chimpanzees at Bossou, Guinea. Primates 20:513-524

Sugiyama Y, Koman J, Sow MB (1988) Ant-catching wands of wild chimpanzees at Bossou, Guinea. Folia Primatol 51:56-60

Suzuki A (1966) On the insect-eating habits among wild chimpanzees living in the savanna woodland of western Tanzania. Primates 7:481-487

Suzuki S, Kuroda S, Nishihara T (1995) Tool-set for termite-fishing by chimpanzees in the Ndoki Forest, Congo. Behaviour 132:219-235

Taylor B (2010) The ants of (sub-Saharan) Africa (Hymenoptera: Formicidae), 10th edn. Available at: http://antbase.org/ants/africa/. Accessed 26 Feb 2011

Tutin CEG, Fernandez M (1992) Insect-eating by sympatric lowland gorillas (Gorilla g. gorilla) and chimpanzees (Pan $t$. troglodytes) in the Lopé Reserve, Gabon. Am J Primatol 28:29-40

Tutin CEG, Ham R, Wrogemann D (1995) Tool-use by chimpanzees (Pan t. troglodytes) in the Lopé Reserve, Gabon. Primates 36:181-192

Uehara S (1982) Seasonal change in the techniques employed by wild chimpanzees in the Mahale Mountains, Tanzania, to feed on termites (Pseudacanthotermes spiniger). Folia Primatol 37:44-76

Uehara S (1986) Sex and group differences in feeding on animals by wild chimpanzees in the Mahale Mountains National Park, Tanzania. Primates 27:1-13

Whiten A, Goodall J, McGrew WC, Nishida T, Reynolds V, Sugiyama Y, Tutin CEG, Wrangham RW, Boesch C (1999) Cultures in chimpanzees. Nature 399:682-685 
Natural history of Camponotus ant-fishing by Mahale chimpanzees

Whiten A, Goodall J, McGrew WC, Nishida T, Reynolds V, Sugiyama Y, Tutin CEG, Wrangham RW, Boesch C (2001) Charting cultural variation in chimpanzees. Behaviour 138:1481-1516

Yamakoshi G (1998) Dietary responses to fruit scarcity of wild chimpanzees at Bossou, Guinea: possible implications for ecological importance of tool use. Am J Phys Anthropol 106:283-295

Yamakoshi G, Myowa-Yamakoshi M (2004) New observations of ant-dipping techniques in wild chimpanzees at Bossou, Guinea. Primates 45:25-32

1
Yamamoto S, Yamakoshi G, Humle T, Matsuzawa T (2008) Invention and modification of a new tool use behavior: ant-fishing in trees by a wild chimpanzee (Pan troglodytes) at Bossou, Guinea. Am J Primatol 70:699-702

Yanoviak SP, Fisher BL, Alonso A (2007) Arboreal ant diversity (Hymenoptera: Formicidae) in a central African forest. Afr J Ecol 46:60-66 